СОЛОМЯНОВА-КИРИЛЬЧУК К. О. ${ }^{1}$, ГРЕБЕНІКОВА О. В.

\title{
ФОРМУВАННЯ СИСТЕМИ ПОКАЗНИКІВ ДІАГНОСТУВАННЯ РИЗИКУ БАНКРУТСТВА ПІДПРИЕМСТВ МАШИНОБУДУВАННЯ
}

\author{
DOI: 10.32620/cher.2019.1.09
}

Постановка проблеми. В Україні питання діагностики ризику банкрутства актуалізується на тлі трансформаційних процесів в економіці. Вимушена переорієнтація на нові ринки і зміни в сталих господарських ланцюгів роблять особливо вразливими підприємства машинобудування. Тому наразі важливо завчасно виявляти проблеми з платоспроможністю і ступінь ризику настання банкрутства підприємств саме цієї галузі. Мета статmi - обгрунтувати методику добору і сформувати систему показників, які забезпечать діагностування ступеню ризику банкрутства на основі даних фінансової звітності підприємства. Об 'єктом дослідження є підприємства машинобудування України та процес формування системи показників, які дозволять визначити ступінь ризику банкрутства суб'єктів господарювання цієї галузі. Методи, використані в дослідженні: методи наукового пізнання, а саме аналіз і синтез, індукція, вимірювання, спостереження, формалізація, логіко-аналітичні прийоми, а також методологічний апарат фінансового аналізу та математичної статистики. Основною гіпотезою дослідження $є$ припущення, що процес відбору показників, що грунтується на методах математичної статистики дозволить уникнути упередженості інших недоліків, які знижують якість діагностування банкрутства підприємств. Виклад основного матеріалу. Існуючі моделі діагностики банкрутства мають суттєві недоліки в частині підходу до відбору показників і кількості класів до яких може відноситись підприємство в залежності від наявного ступеню ризику банкрутства. Тому авторами було запропоновано власний підхід для відбору діагностично значущих фінансових коефіцієнтів на базі tкритерію Стьюдента, U-тесту Манна-Уітні та коефіцієнту кореляції. Та на його основі сформовано систему показників діагностування банкрутства. Оригінальність та практична значимість дослідження полягає в тому, що математично обгрунтовано систему показників, яка максимально підкреслює приналежність машинобудівного підприємства до того чи іншого класу ризику банкрутства, що відповідає сучасним принципам доказових досліджень. Висновки та перспективи подальших досліджень: на основі визначеної системи показників буде побудовано модель діагностування банкрутства машинобудівних підприємств України.

Ключові слова:

діагностування банкрутства, система показників, параметричні критерії, непараметричні критерії, фінансові коефіцієнти, підприємства машинобудування, ризик банкрутства.

\section{FORMATION OF THE INDICATORS SYSTEM FOR DIAGNOSTIC MACHINE-BUILDING ENTERPRISES FAILURE RISK}

Formulation of the problem. The issues of failure risk diagnosing were actualized in Ukraine against the background of transformation processes in the economy. Enterprises are particularly vulnerable due to the forced reorientation to new markets and changes in permanent business relations. Therefore, it is now important to identify in insolvency problems and the risk of enterprises' failure of this industry. The purpose of the research is to substantiate the method of selection and form a system of indicators that will provide diagnostics of the failure risk based on the financial statements of the company. The subject of the re-

${ }^{1}$ Соломянова-Кирильчук Катерина Олегівна, аспірант кафедри «Фінанси», Національний аерокосмічний університет ім. М. Є. Жуковський «Харківський авіаційний інститут», м. Харків, Україна.

Solomianova-Kirilchuk Kateryna, post-graduate student of Finance Department National Aerospace University «Kharkiv Aviation Institute», Kharkiv, Ukraine.

ORCID ID: 0000-0003-1920-4321

e-mail: solomyanova-kirilchuk@ukr.net

${ }^{2}$ Гребенікова Олена Володимирівна, канд. екон. наук, доцент кафедри «Фінанси», Національний аерокосмічний університет ім. М. Є. Жуковський «Харківський авіаційний інститут», м. Харків, Україна.

Grebenikova Olena, Ph.D. in Economics, Assistant professor of Finance Department National Aerospace University «Kharkiv Aviation Institute», Kharkiv, Ukraine.

ORCID ID: 0000-0003-2695-4630

e-mail: grebenikova@ukr.net 
search is the Ukrainian machine-building enterprises and the process of forming a system of indicators, which will determine the failure risk of business entities. The methods of the research: methods of scientific knowledge, such as analysis and synthesis, induction, measurement, observation, formalization, logical and analytical techniques, as well as the methodological apparatus of financial analysis and mathematical statistics. The hypothesis of the research is the assumption that the process of selecting indicators based on the methods of mathematical statistics will avoid bias of other shortcomings that reduce the quality of enterprises' failure diagnosing. The statement of basic materials. The existing models of failure diagnostics have serious shortcomings in terms of the approach to the selection of indicators and the number of classes, which the enterprise may belong to, depending on the existing risk of bankruptcy. Therefore, the authors proposed their own approach to the selection of diagnostically significant financial ratios based on the Student's t-test, the Mann-Whitney U-test and the correlation coefficient. A system of indicators of failure diagnosing has formed based on this approach. The originality and practical significance of the research is that a system of indicators is mathematically substantiated, what corresponds to the modern principles of evidence-based research and maximally emphasizes that the machine-building enterprise belongs to a particular failure risk class. Conclusions and perspectives of further research: the researchers are going to build a failure diagnostic model for Ukrainian machine-building enterprises based on the determined system of indicators.

Key words:

failure diagnostic, a system of indicators, parametric criteria, non-parametric criteria, financial ratios, machine-building enterprises, failure risk.

\section{ФОРМИРОВАНИЕ СИСТЕМЫ ПОКАЗАТЕЛЕЙ ДИАГНОСТИРОВАНИ РИСКА БАНКРОТСТВА ПРЕДПРИЯТИЙ МАШИНОСТРОЕНИЯ}

Постановка проблемыл. В Украине вопросы диагностирования риска банкротства актуализировались на фоне трансформационных процессов в экономике. Из-за вынужденной переориентации на новые рынки и изменения постоянных хозяйственных связей особенно уязвимыми являются предприятия машиностроения. Поэтому сейчас важно заблаговременно выявлять проблемы с платежеспособностью и степень риска наступления банкротства предприятий именно этой отрасли. Цель статьи - обосновать методику отбора и сформировать систему показателей, которые обеспечат диагностику степени риска банкротства на основе данных финансовой отчетности предприятия. Объектом исследования являются предприятия машиностроения Украины и процесс формирования системы показателей, которая позволит определить степень риска банкротства субъектов хозяйствования этой отрасли. Memoдbl, ucnoльзуемые в исследовании: методы научного познания, а именно анализ и синтез, индукция, измерения, наблюдения, формализация, логико-аналитические приемы, а также методологический аппарат финансового анализа и математической статистики. Основной гипотезой исследования является предположение, что процесс отбора показателей, основанный на методах математической статистики, позволит избежать предвзятости других недостатков, которые снижают качество диагностирования банкротства предприятий. Изложение основного материала. Существующие модели диагностики банкротства имеют серьёзные недостатки в части подхода к отбору показателей и количества классов, к которым может относиться предприятие в зависимости от имеющейся степени риска банкротства. Поэтому авторами был предложен собственный подход к отбору диагностически значимых финансовых коэффициентов на базе t-критерия Стьюдента, U-теста Манна-Уитни и коэффициента корреляции. На основе этого подхода сформирована система показателей диагностирования банкротства. Оригинальность и практическая значимость исследования заключается в том, что математически обоснована система показателей, соответствующая современным принципам доказательных исследований, которая максимально подчеркивает принадлежность машиностроительного предприятия к тому или иному классу риска банкротства. Bblвoдbl $u$ nepспективы дальнейших исследований: на основе сформированной системы показателей будет построена модель диагностирования банкротства машиностроительных предприятий Украины.

\section{Ключевые слова:}

диагностирование банкротства, система показателей, параметрические критерии, непараметрические критерии, финансовые коэффициенты, предприятия машиностроения, риск банкротства.

Постановка проблеми. В країнах 3 вільним ринком механізм банкрутства дозволяє природним чином регулювати відносини між суб'єктами економічних відносин і забезпечувати механізми здорової конкуренції. В
Україні останніми роками розпочато глибинні реформи, що відкривають нові можливості для розвитку економіки держави, але можуть послабити стан окремих учасників ринку, які 3 тих чи інших причин неспроможні своєчас- 
но і адекватно відреагувати на зміни $[1,2]$. Таким чином, в Україні питання завчасної діагностики, профілактики і подолання кризових явищ залишаються актуальними.

Підприємство будь якої галузі й розміру може виявитися нездатним розрахуватися за своїми борговими зобов'язаннями. Тобто в залежності від поточної ситуації усі підприємства мають певний ступінь ризику неплатоспроможності і банкрутства. Масове погіршення ситуації може викликати системні економічні проблеми. Тому важливо своєчасно діагностувати проблеми і вжити превентивних заходів.

Машинобудування завжди було важливою ланкою у народному господарстві України, що відмічають і інші дослідники [3]. Під час криз воно виявлялось однією 3 найстійкіших галузей. Окрім того, продукція наукомістких інноваційних галузей формує максимальну додану вартість і є характерною для країн 3 високим потенціалом. Зазначені факти зумовили актуальність дослідження ризиків банкрутства і кризових процесів саме у цій галузі.

Аналіз останніх досліджень та публікацій. Питаннями діагностування банкрутства займалися багато зарубіжних і вітчизняних вчених, зокрема: Е. Альтман [4], У. Бівер, Дж. Аргенті, А. П. Ковальов, О. В. Максімов, Л. О. Лігоненко, О. О. Терещенко, А. М. Поддєрьогін, І. А. Бланк, Т. С. Клебанова, Е. А. Андрущак, Н. Н., Г. Д. Боднер [5], I. I. Нескородєва [6], Н. Н. ПойдаНосик [7], О. Л. Тимощук [8] й інші. Незважаючи на численність досліджень, запропоновані в них методики і моделі мають суттєві недоліки: 1) майже не враховується галузева складова; 2) відсутня градація ступенів ризику банкрутства підприємства; 3) моделі не оновлюються з урахування макроекономічної ситуації характерної для конкретного часового проміжку; 4) добір показників для моделей, що розробляються у цих дослідженнях, відбувається на основі аналітичних методів і експертних оцінок i, як правило, не має математичного підгрунтя, яке забезпечує виявлення існуючих суттєвих закономірностей.

Важливість виключення зазначених недоліків обумовлює необхідність розробки нових підходів до діагностики банкрутства.

Аналіз позитивних і негативних рис існуючих методів аналізу дозволив визначити, що використання кількісних є найбільш доцільним і зручним [9]. Враховуючи багатовимірність описання станів підприємства, як складної виробничо-економічної системи перевагу було надано методології дискримінантного аналізу на основі коефіцієнтів (показників), які розраховуються за даними бухгалтерської звітності і всебічно описують стан підприємства.

Зазвичай дослідники обмежуються лише однією функцією, за допомогою якої отримані результати дискримінуються лише на два класи. Але в загальному випадку максимальна кількість дискримінантних функцій може дорівнювати кількості класів поділу без одиниці $[10$, с. 126]. Тому автори визначили за необхідне побудувати градаційну модель, що дозволить діагностувати ступінь поточного ризику банкрутства підприємства, а не лише констатувати приналежність його до класу платоспроможних чи неплатоспроможних.

Отже, метою статті і першим етапом, який зумовлює успішність подальших розрахунків, є формування системи показників, на основі яких буде побудовано модель. 3 одного боку вони мають всебічно описувати стан підприємства, з іншого - до моделі мають увійти тільки статистично значущі показники, які найбільше характеризують різницю між наявним ступенем ризику банкрутства підприємств у різних класах.

Виклад основного матеріалу дослідження. Добір показників було здійснено у декілька етапів.

1. Визначення 4 класів, що характеризують різний ступень ризику банкрутства, і критеріїв віднесення спостережень до кожного $з$ них.

2. Формування бази спостережень (об'єктів) для аналізу. Під одним спостереженням маються на увазі дані бухгалтерської звітності одного машинобудівного підприємства за один календарний рік за 2013-2018 роки [11].

3. Розподіл спостережень за класами.

4. Визначення первісного пулу коефіцієнтів, які всебічно описують фінансовогосподарський стан підприємства.

5. Розрахунок коефіцієнтів 3 п.4 для кожного спостереження.

6. Відбір статистично значущих коефіцієнтів, що дозволяють диференціювати об'єкти за класами. 
На першому етапі було визначено чотири групи підприємств, які за ступенем ризику настання банкрутства було поділено на:

- малоймовірне (N - normal);

- невеликий ризик (T - temporary problems);

- висока ймовірність (I - insolvency);

- критична ймовірність (C - crisis).

Підприємство відносили до тієї чи іншої групи за принципом, який викладено у Наказі Міністерства економіки України «Про затвердження Методичних рекомендацій щодо виявлення ознак неплатоспроможності підприємства та ознак дій з приховування банкрутства, фіктивного банкрутства чи доведення до банкрутства, фіктивного банкрутства чи доведення до банкрутства» [12]. Бо саме їх розроб- лена для забезпечення однозначності підходів при оцінюванні фінансово-господарського стану підприємств. Однак умови рознесення підприємств за класами платоспроможності, що запропоновано у методичних рекомендаціях було дещо модифіковано. Це обумовлено, насамперед двома причинами. По-перше, на основі умов, які описані у методиці, не завжди можливо коректно і однозначно класифікувати досліджуваний об’єкт. А по-друге, загальний стан підприємств галузі, фінансова політика підприємств, а також якість звітностей викривлюють загальний поділ на класи підприємств машинобудування.

Отже, у табл. 1 наведено умови віднесення досліджуваних підприємств (спостережень) до певного класу.

Т а б лиц я 1

\section{Принцип поділу досліджуваних підприємств на класи}

\begin{tabular}{|c|c|c|c|c|}
\hline \multirow{3}{*}{ Клас (група) } & \multicolumn{4}{|c|}{ Критеріальні значення коефіцієнта } \\
\hline & $\begin{array}{c}\text { Коефіцієнт } \\
\text { поточної плато- } \\
\text { спроможності }\end{array}$ & $\begin{array}{c}\text { Коефіцієнт } \\
\text { забезпечення } \\
\text { власними } \\
\text { засобами }\end{array}$ & $\begin{array}{l}\text { Коефіцієнт } \\
\text { покриття }\end{array}$ & Чистий прибуток \\
\hline & 1 & 2 & 3 & 4 \\
\hline \multirow{2}{*}{$\begin{array}{l}\text { Низький ступінь ризику } \\
\text { банкрутства } \\
\text { (N-normal) }\end{array}$} & $>0$ & \multirow[t]{2}{*}{$>0,1$} & \multirow[t]{2}{*}{$>1,5$} & $>0$ \\
\hline & $<0$ & & & $\begin{array}{c}>0 \\
(\text { якщо }|г \mathrm{p} .4 / \Gamma \mathrm{p} .1| \geq 0,85)\end{array}$ \\
\hline \multirow{2}{*}{$\begin{array}{l}\text { Середній ступінь ризи- } \\
\text { ку банкрутства } \\
\text { (T-temporary) }\end{array}$} & $<0$ & \multirow[t]{2}{*}{$>0,1$} & \multirow[t]{2}{*}{$>1,5$} & $\begin{array}{c}>0 \\
\text { (якщо |гр.4/гр. } 1 \mid \leq 0,10)\end{array}$ \\
\hline & $<0$ & & & $<0$ \\
\hline \multirow{3}{*}{$\begin{array}{l}\text { Високий ступінь } \\
\text { ризику банкрутства } \\
\text { (I-insolvency) }\end{array}$} & \multirow{3}{*}{$\begin{array}{l}<0 \\
>0\end{array}$} & $<0,1$ & $1,1<\mathrm{K}_{n} \leq 1,5$ & \multirow{3}{*}{$\begin{array}{l}<0 \\
>0\end{array}$} \\
\hline & & $<0,1$ & $>1,5$ & \\
\hline & & $>0,1$ & $<1,5$ & \\
\hline $\begin{array}{l}\text { Критичний ступінь } \\
\text { ризику банкрутства } \\
\text { (C-crisis) }\end{array}$ & $<0$ & $<0,1$ & $<1,05$ & $<0$ \\
\hline
\end{tabular}

Джерело: розроблено авторами на підставі [13]

Аналітичним шляхом більш ніж зі 300 спостережень для дослідження було відібрано 172. Було вилучено підприємства 3 валютою балансу менш ніж 10 млн.грн., а також ті, що відрізнялися низькою якістю і неповнотою даних. 3 тих, які залишились базуючись на принципі, що представлено у таблиці 1, було сформовано чотири класи: N (22 спостереження), T (48 спостереження), I (73 спостереження), С (29 спостережень).

При формуванні первісної системи показників (коефіцієнтів) дослідники, здебільшого спираються на показники, що описують суто фінансову складову стану підприємства не приділяючи достатньої уваги тим, що характеризують майновий стан, основні засоби підприємства, його господарську діяльність. Але перелічені показники відіграють суттєву роль при діагностуванні платоспроможності машинобудівних підприємств.

Отже, авторами сформовано первісну систему коефіцієнтів (табл. 2), що найповніше описує фінансово-господарський стан підприємств і найчастіше використовуються 
Т а бли ц я 2

Первісна система коефіцієнтів для діагностування ступеню платоспроможності

\begin{tabular}{|c|c|}
\hline $\begin{array}{c}\text { Номер } \\
\text { показника }\end{array}$ & Назва показника \\
\hline & \multirow{2}{*}{$\frac{2}{\text { Kоефішіснти майнового стану }}$} \\
\hline & \\
\hline 1 & Коефіцієнт мобільності \\
\hline 2 & Коефіцієнт виробничого потенціалу \\
\hline 3 & Індекс постійного активу \\
\hline 4 & Коефіцієнт трансформації \\
\hline 5 & Частка основних засобів у активі \\
\hline 6 & Частка нематеріальних активів у активі \\
\hline 7 & Коефіцієнт зносу основних засобів \\
\hline 8 & Фондовіддача \\
\hline 9 & Рентабельність (збитковість основних засобів) \\
\hline \multicolumn{2}{|r|}{ Коефіцієнти оборотних активів } \\
\hline 10 & Коефіцієнт оборотності запасів \\
\hline 11 & Частка виробничих запасів у запасах \\
\hline 12 & Частка незавершеного виробництва у запасах \\
\hline 13 & Частка готової продукції у запасах \\
\hline 14 & Коефіцієнт оборотності дебіторської заборгованості \\
\hline 15 & Коефіцієнт оборотності чистої дебіторської заборгованості \\
\hline 16 & Забезпеченість запасів ВОЗ \\
\hline 17 & Забезпеченість ОА ВО3 \\
\hline 18 & Співвідношення ДЗ и КЗ \\
\hline \multicolumn{2}{|r|}{ Коефіціснти, що характеризують власний капітал } \\
\hline 19 & Коефіцієнт оборотності ЧКЗ \\
\hline 20 & Коефіцієнт фінансової автономії \\
\hline 21 & Коефіцієнт фінансової стабільності \\
\hline 22 & Коефіцієнт фінансової стійкості \\
\hline 23 & Коефіцієнт маневреності власного капіталу \\
\hline 24 & Коефіцієнт структури довгострокових джерел фінансування \\
\hline 25 & Коефіцієнт структури покриття довгострокової заборгованості \\
\hline 26 & Коефіцієнт концентрації короткострокової заборгованості \\
\hline 27 & Коефіцієнт накопичення власного капіталу \\
\hline \multicolumn{2}{|r|}{ Показники фінансової стійкості } \\
\hline 28 & Частка ВОЗ в активах \\
\hline 29 & Коефіцієнт покриття запасів нормальними джерелами фінансування \\
\hline 30 & Коефіцієнт іммобілізації ВОЗ \\
\hline 31 & Коефіцієнт автономії джерел формування запасів \\
\hline 32 & Коефіцієнт маневреності ВО3 \\
\hline 33 & Коефіцієнт Бівера \\
\hline \multicolumn{2}{|r|}{ Показники платоспроможності і ліквідності } \\
\hline 34 & Коефіцієнт покриття \\
\hline 35 & Коефіцієнт швидкої ліквідності \\
\hline 36 & Коефіцієнт абсолютної ліквідності \\
\hline 37 & Коефіцієнт ліквідної платоспроможності \\
\hline 38 & Коефіцієнт забезпеченості поточної діяльності власними коштами \\
\hline \multicolumn{2}{|r|}{ Коефіцієнти, що характеризують рентабельність та ділову активність } \\
\hline 39 & Операційний цикл \\
\hline 40 & Фінансовий цикл \\
\hline 41 & Коефіцієнт оборотності власного капіталу \\
\hline 42 & Коефіцієнт оборотності іммобільних активів \\
\hline 43 & Коефіцієнт оборотності мобільних активів \\
\hline 44 & Коефіцієнт оборотності готової продукції \\
\hline 45 & Коефіцієнт оборотності незавершеного виробництва \\
\hline 46 & Рентабельність активів \\
\hline 47 & Рентабельність інвестованого капіталу \\
\hline
\end{tabular}




\begin{tabular}{|c|c|}
\hline & Продовження табл. 2 \\
\hline 1 & 2 \\
\hline 48 & Рентабельність власного капіталу \\
\hline 49 & Рентабельність необоротного капіталу \\
\hline 50 & Рентабельність оборотного капіталу \\
\hline 51 & Рентабельність продукції \\
\hline 52 & Рентабельність операційної діяльності \\
\hline 53 & Рентабельність виробництва \\
\hline 54 & Рентабельність продажів за чистим прибутком \\
\hline 55 & Коефіцієнт дивідендних виплат \\
\hline 56 & EBIT (прибуток до вирахування відсотків і податків) \\
\hline 57 & Коефіцієнт відношення боргу до ЕВIT \\
\hline 58 & Рентабельність продаж на основі чистого грошового потоку \\
\hline 59 & Коефіцієнт тривалості обслуговування боргу \\
\hline 60 & Співвідношення операційного і інвестиційного потоків \\
\hline
\end{tabular}

при комплексному фінансовому аналізі. До їі складу увійшло 60 коефіцієнтів, перелік яких представлено у табл. 2.

Далі ці показники було розраховано для кожного спостереження. Щоб узгодити часові розбіжності форм фінансової звітності, показники балансу було взято середні за період.

Наступний етап - відбір найбільш значущих показників діагностики ризику банкрутства буде здійснюватися тричі, за парами класів N і T, T і I, I і С., оскільки значення тих коефіцієнтів, що суттєво відрізняються, наприклад, у представників групи $\mathrm{N}$ і T, можуть бути дуже схожими у спостережень групи T i I.

Селекція показників із первісної системи базується на наступних принципах:

- відповідність системи ознак задачам діагностичного дослідження;

- можливість чіткого визначення алгоритмів розрахунку показників-індикаторів кризи;

- охоплення максимальної кількості аспектів діяльності підприємства;

- лінійна незалежність один від одного показників, які ввійшли до системи, та максимальна кореляція з тими, що не ввійшли до неї;

- оптимальна кількість показників, яка дозволить, з одного боку, максимально описати стан підприємства, з іншого - спростити систему;

• кожен показник має бути підпорядкований нормальному розподілу.

Формування діагностичної системи показників, що відповідає зазначеним вимогам, здійснювалося на основі показників tкритерію Стьюдента, непараметричного Uтесту Манна-Уітні і коефіціснту кореляції.

Розрахунки проводились за допомогою ППП Statistica та EXEL у декілька етапів.

1. Для перевірки гіпотези щодо наявності статистично значущої відмінності між значеннями коефіцієнтів у класах, що порівнюються, використовуються статистичні тести для незалежних вибірок: t-критерій Стьюдента і U-тест Манна-Уітні. Стосовно того, який критерій $є$ пріоритетним існують декілька думок.

Так деякі дослідники стверджують, що t-критерій Стьюдента використовується, якщо значення коефіцієнтів у обидвох класах підпорядковуються нормальному розподілу. Якщо хоча б для одного класу значення коефіцієнта не підпорядковуються нормальному розподілу, використовується непараметричний критерій Манна-Уітні, оскільки вибірки є незалежними [16, с.212].

3 іншого боку є думка, що за умови, що об'єм вибірки більший за 20 , то розподіл U статистики швидко сходиться до нормального [17]. У випадку даного дослідження об'єм кожної з вибірок перевищує 20 спостережень.

Автори підтримують думку [18], щодо універсальної рекомендації - використовувати обидва методи, якщо результати не будуть мати суттєвої різниці, приймати рішення на ïх основі.

Отже для кожного коефіцієнта на основі значень за двома суміжними класами роз- 
раховувалось фактичне значення критерію Стьюдента та U-тест. Показник відбирався до подальшого дослідження, якщо p-value для обох критеріїв був менший за 0,05. У такому випадку з вірогідністю 95\% середні значення коефіцієнту за класами відрізняються., тобто різниця між підприємствами у різних класах є суттєвою і статистично достовірною.

2. Оскільки параметричні методи мають більшу статистичну потужність [19] далі відбір грунтувався на критерії Стьюдента. Значення t-критерію за модулем для коефіцієнтів, що залишилися, було проранжовано у порядку зменшення значущості. Перший коефіцієнт відбирався до результуючої системи показників. Кожен наступний показник порівнювався за коефіцієнтом кореляції з тими, що вже було відібрано. Якщо коефіцієнт кореляції був менший за 0,5 для класів $\mathrm{N} \mathrm{i} \mathrm{T,} \mathrm{T} \mathrm{і} \mathrm{I,}$ або за 0,4 для класів I та C, то показник додавався до результуючої системи.

Зазначені операції було здійснено для кожної пари класів. Таким чином, було сформовано наступні системи показників.

Низький/середній ступінь ризику банкрутства:

- частина незавершеного виробництва у запасах;

- коефіцієнт фінансової стійкості

- коефіцієнт іммобілізації ВОЗ;

- коефіцієнт абсолютної ліквідності;

- коефіцієнт ліквідної платоспроможності;

- рентабельність продажів за чистим прибутком.

Середній/високий ступінь ризику банкрутства:

- частка основних засобів у активі

- коефіцієнт зносу основних засобів

- фондовіддача

- забезпеченість запасів ВОЗ;

- частка ВОЗ в активах;

- коефіцієнт абсолютної ліквідності;

- коефіцієнт оборотності іммобільних активів;

- коефіцієнт оборотності незавершеного виробництва;

- рентабельність продукції.

Високий/критичний ступінь ризику банкрутства:

- коефіцієнт трансформації;

- частка основних засобів у активі;
- коефіцієнт оборотності запасів;

- забезпеченість ОА ВОЗ;

- коефіцієнт структури довгострокових джерел фінансування;

- частка ВОЗ в активах;

- коефіцієнт автономії джерел формування запасів;

- коефіцієнт швидкої ліквідності;

- коефіцієнт абсолютної ліквідності;

- фінансовий цикл;

- коефіціснт оборотності іммобільних активів;

- рентабельність інвестованого капіталу;

- рентабельність виробництва.

Висновки та перспективи подальших досліджень. Отже отримано системи показників, які всебічно описують досліджувані об'єкти і якнайбільше підкреслюють різницю i забезпечують максимальну дискримінацию спостережень між двома суміжними групами. На основі отриманих результатів буде побудовано градаційну системну математичну модель діагностування ризику банкрутства підприємств машинобудування.

\section{Література}

1. Звєряков M. I. Уроки ринкової трансформації в Україні / М.І. Звєряков // Економіка України. - 2016. - № 8 (657). - С 7-25.

2. Білорус О. Г. Глобальна структурна криза та трансформації фінансової світсистеми / О. Г. Білорус // Фінанси України. 2014. - № 4. - С. 32 - 45.

3. Кривецький I. O. Аналізування стану та тенденцій розвитку машинобудівних підприємств в Україні / I. О. Кривецький // Вісник Національного університету "Львівська політехніка". Менеджмент та підприємництво в Україні: етапи становлення і проблеми розвитку. - 2014. - № 794. - С. 29 - 36.

4. E. Altman. Financial Ratios, Discrimi ant Analysis and the Prediction of Corporate Bankruptcy // Journal of Finance. - 1968. №22, pp. 589-610.

5. Боднер Г.Д. Методи прогнозування фінансового стану підприємства на сучасному / Г.Д. Боднер, Д.М. Хараім // Науковий вісник: Фінанси, банки, інвестиції - 2014 №2 - C. $14-18$. 
6. Нескородєва I. I. Діагностика банкрутства підприємства 3 використанням технології факторного аналізу / І. І. Нескородєва, С.А. Пустовгар // Фінанси України. - 2014. № 7. - C. $114-125$.

7. Тимощук О. Л. Оцінювання ймовірності банкрутства підприємств за допомогою дискримінантного аналізу та нейронних мереж / О. Л. Тимощук, К. М. Дорундяк // Системні дослідження та інформаційні технології. - 2018 - № 2 - С. 22 - 34 .

8. Пойда-Носик Н. Н. Дослідження сутності та причин банкрутства підприємств / Н. Пойда-Носик // Облік, аудит і аналіз. - 2009. - №4 (17). - С. 304 - 308.

9. Гребенікова О.В. Дискримінантна модель діагностики неплатоспроможності українських підприємств машинобудування / О.В. Гребенікова, К.О. СоломяноваКирильчук // Фінанси України - 2007. - №12. - С. $129-137$.

10. Григорук T.M. Багатомірне економіко-статистичне моделювання: Навч. посібник для студентів ВНЗ. - Львів: «Новий світ2000». 2006. - 148c.

11. Офіційний сайт Агентства з розвитку інфраструктури фондового ринку України [Електронний ресурс]. - Режим доступу до сайту: www.smida.gov.ua/emitents

12. Наказ Міністерства економіки України «Про затвердження Методичних рекомендацій щодо виявлення ознак неплатоспроможності підприємства та ознак дій з приховування банкрутства, фіктивного банкрутства чи доведення до банкрутства» від 19.01.2006 № 14 [Електронний ресурс]. - Режим доступу до сайту:

https://zakon.rada.gov.ua/rada/show/v0014665-06

13. Шеремет А.Д. Методика финансового анализа деятельности коммерческих организаций 2-е изд., перераб. и доп./ А.Д. Шеремет, Е.В. Негашев. - М.: ИНФРА-М, 2008. -208 c.

14. Крамаренко Г.О. Фінансовий аналіз. Підручник. / Г.О. Крамаренко, О.С. Чорна // К.: Центр учбової літератури, 2008. - 392 с.

15. Лахтіонова Л.А. Аналіз платоспроможності та ліквідності суб'єктів підприємницької діяльності: Монографія / Л. А. Лахтіонова. - К.: КНЕУ, 2010. -657 с.
16. Кельмансон И. А. Методология исследования в клинической психологии: учеб. пособие. - Санкт-Петербург: СпецЛит, 2017. $-328 \mathrm{c}$.

17. Офіційний сайт ППП Statistica розділ «Help» [Електронний ресурс]. - Режим доступу до сайту: http://documentation.statsoft.com/STATISTICA Help.aspx?path=Nonparametrics/Nonparametric Analysis/Dialogs/StartupPanel/NonparametricsS tatisticsStartupPanelMannWhitneyUtest

18. Корнеев A. А. Условия применимости критериев Стьюдента и Манна-Уитни / А. А. Корнеев, А. Н. Кричевец // Психологический журнал - 2011. - Т. 32. - № 1 - с. 97-110.

19. Электронный учебник по статистике компании StatSoft, Inc., создателя системы STATISTICA [Електронний ресурс]. - Режим доступу до сайту: http://statsoft.ru/home/textbook/default.htm

\section{References}

1. Zveryakov, M. I. (2016). Lessons of the market transformation in Ukraine. Economy of Ukraine, 8 (657), 7-25.

2. Bilorus, O. G. (2014). Global structural crisis and transformation of the world financial system. Finance of Ukraine, 4, $32-45$.

3. Kryvetskyi, I. O. (2014). Analyzing the status and trends of development of machinebuilding enterprises in Ukraine. Thematic Series of Visnyk (Official Gazette) of Lviv Polytechnic National University: Management and Entrepreneurship in Ukraine: the stages of formation and problems of development, 794, 2936.

4. Altman, E. (1968) Financial Ratios, Discriminant Analysis and the Prediction of Corporate Bankruptcy. Journal of Finance, 22, 589-610.

5. Bodner, H. D. \& Harpurpose, D. M. (2014). Methods of forecasting the financial condition enterprises at the present stage. Scientific Herald: Finance, Banks, Investments, 2, 1418.

6. Neskorodieva, I. I. \& Pustovgar, S. A. (2014). Diagnostics of bankruptcy by using factor analysis technology. Finance of Ukraine, 7, $114-125$. 
7. Tymoshchuk, O. L, Dorundiak, K. M. (2018). Assessment of the probability of bankruptcy of companies using discriminant analysis and neural networks. System research and information technologies, 2, $22-34$.

8. Poyda-Nosyk, N. N. (2009). Inves?igation of the essence and causes of bankruptcy of enterprises. Accounting, audit and analysis, 4 (17), 304-308.

9. Grebenikova, O. V. \& SolomianovaKyrylchuk, K. O. (2007). Discriminant model for insolvency diagnostic of Ukrainian machinebuilding enterprises. Finance of Ukraine, 12, 129 -137 .

10. Hryhoruk, T. M. (2006). Multi?imensional economic-statistical modeling: a guide for university students. Lviv: Novyii Svit 2000, 148.

11. Oficcial webpage of Stock market infrastructure development agency of Ukraine. Retrieved from: www.smida.gov.ua/emitents

12. The order of the Ministry of Economy of Ukraine On Approval of Methodological Recommendations on Identification of Insolvency Signs of the Enterprise and Signs of Action to Conceal Bankruptcy, Fictitious Bankruptcy or to bring Bankruptcy from January 19, 2006 No. 14 Retrieved from:

Стаття надійшла

до редакції : 17.01.2019 p. https://zakon.rada.gov.ua/rada/show/v0014665.

13. Sheremet, A. D., Negashev, E. V. (2008). Methodology of financial analysis of the activities of commercial organizations (second edition). Moscow: INFRA-M, 208.

14. Kramarenko, H. O. Chorna, O. Y. (2008). Financial analysis. Textbook. Kyiv: Center for Educational Literature, 392.

15. Lahtionova, L. A. (2010) Analysis of Solvency and Liquidity of Business Entities: Monography. Kyiv: KNEU, 657.

16. Kelmanson, I. A. (2017). Research Methodology in Clinical Psychology: study guide. Saint-Petersburg: SpetsLit, 328.

17. Official webpage of Statistica software. Section «Help». Retrieved from: http://documentation.statsoft.com/STATISTICA Help.aspx?path=Nonparametrics/Nonparametric Analysis/Dialogs/StartupPanel/NonparametricsS tatisticsStartupPanelMannWhitneyUtest

18. Korneev, A. A. \& Krichevets, A. N. (2011). Conditions for Student t-test and Mann-Whitney U-test application. Psych?logical journal, vol. 32 (1), 97-110.

19. Online tutorial on statistics of StatSoft, Inc., the creator of the STATISTICA software. Retrieved from: http://statsoft.ru/home/textbook/default.htm.

Стаття прийнята

до друку: 29.03.2019 р.

Бібліографічний опис для цитування :

Соломянова-Кирильчук К. О. Формування системи показників діагностування ризику банкрутства підприємств машинобудування / К. О. Соломянова-Кирильчук, О. В. Гребенікова // Часопис економічних реформ. - 2019. - № 1 (33). - С. 67-75. 